\title{
Developing the Digital Culture among the Students of Educational Faculties in Prince Sattam Bin Abdulaziz University
}

\author{
Alyaa Omar kamel Faraj ${ }^{1} \&$ wedad Abdullahn Naser sharabi ${ }^{1}$ \\ ${ }^{1}$ Associate Professor of Education Fundamentals, Faculty of Education in Dalam, Prince Sattam bin Abdulaziz \\ University, Al-Dilam 16213, Saudi Arabia \\ Correspondence: Alyaa Omar kamel Faraj, Associate Professor of Education Fundamentals, Faculty of Education in \\ Dalam, Prince Sattam bin Abdulaziz University, Al-Dilam 16213, Saudi Arabia.
}

Received: November 24, 2020

Accepted: January 6, 2021

Online Published: January 13, 2021

doi:10.5430/ijhe.v10n3p158

URL: https://doi.org/10.5430/ijhe.v10n3p158

\begin{abstract}
The study was aimed to show the reality of practicing digital culture among students of the Education Faculties at Prince Sattam bin Abdulaziz University from their point of view, and to explain the obstacles and problems facing its implementation, and to monitor the university's efforts in developing digital culture among its students. To achieve these aims, a descriptive method was used, and the researchers designed a questionnaire consisting of (32) items. It was distributed on three domains, and the sample was chosen randomly from the students of Prince Sattam bin Abdulaziz University (180), and the results revealed that the approval of the students of Prince Sattam bin Abdulaziz University on the reality of the university's development of digital culture came with a medium degree. As for the university's efforts to develop a digital culture among students came with a high degree, and the results showed that there are statistically significant differences in the viewpoint of the sample members towards the reality of digital culture among the students of the education faculties at the university according to the gender variable in favor of females, and specialization (in favor of kindergartens), and according to the academic year variable (in favor of the fourth year), the study recommends setting a strategic plan to promote digital culture and digital transformation in the education faculties and to invest modern communication technologies in supporting and developing educational technologies at the university.
\end{abstract}

Keywords: development, digital culture, education faculties, Prince Sattam Bin Abdulaziz University

\section{Introduction}

The tremendous developments in the information and communication technology field have affected many economic, social, and cultural life aspects, the production access to and possession of information has become one of the most important priorities of individuals and societies, nevertheless, these developments have produced many new challenges that differ from the previous ones, which have become imperative for societies wishing to keep pace with these developments, will surpass them by adopting many technological means.

The contemporary scientific and technological revolution depends on the endless and non-renewable flow of knowledge and ideas, and scientific advances in the fields of satellites, computers, and microelectronics have helped to store, operate, retrieve and transmit huge amounts of information and how they are used and implications for that, and in this context information technology has emerged, that technology which is related to collecting, communicating, storing, retrieving and processing information (Tashur, 2014),

The study (Nabti\& Bettmit, 2012) indicates that with the development of information and communication technology and the emergence of the third wave, and the accompanying information and knowledge societies up to the digital age, visions directed towards investing in the human and intellectual factor to find a suitable place for it in that global system.

In the same context, Mahmoud's study (2016) confirmed that the rapid information and communication technology developments, the internet increasing growth, and the revolution that it has brought in the scientific community, now requires a review of science education programs to prepare individuals with high science and technological qualifications who can deal with advanced technological devices and equipment to face the huge knowledge flow and help them acquire knowledge related to the information revolution and the values, trends and scientific skills 
associated with this knowledge that enable them to deal with the data of this information revolution so that students can acquire information culture that enables them to coexistence in the information society.

Of Course, it has become imperative to use terms that are in line with the successive transformations of the information revolution, including the term digital culture that refers to new data imposed by the world of scientific and civilization development, this culture has united the world people and made them yearn to form a wide knowledge, and this unified society has come to be called differently, including the knowledge society and the information society, where knowledge becomes the most important source of development, and knowledge production becomes one of the most important sources of national income- the information society, as it provides a huge amount of information while employing it for the benefit of society (ESCWA, 2018), the digital culture was defined as "the use of technical means, digital devices, and systems to do services in the society that will adhere the society culture ethics because this digital communication and interaction may become the intellectual origins that must be taken into care" Therefore, the starting point was to instill this digital culture in the generations and connect it to their cultural customs, through educational institutions (Anthony, 2015).

Digital culture refers to the ability to communicate with others through social media and enter the world of technology and information technology, and it can be illustrated in the following figure:

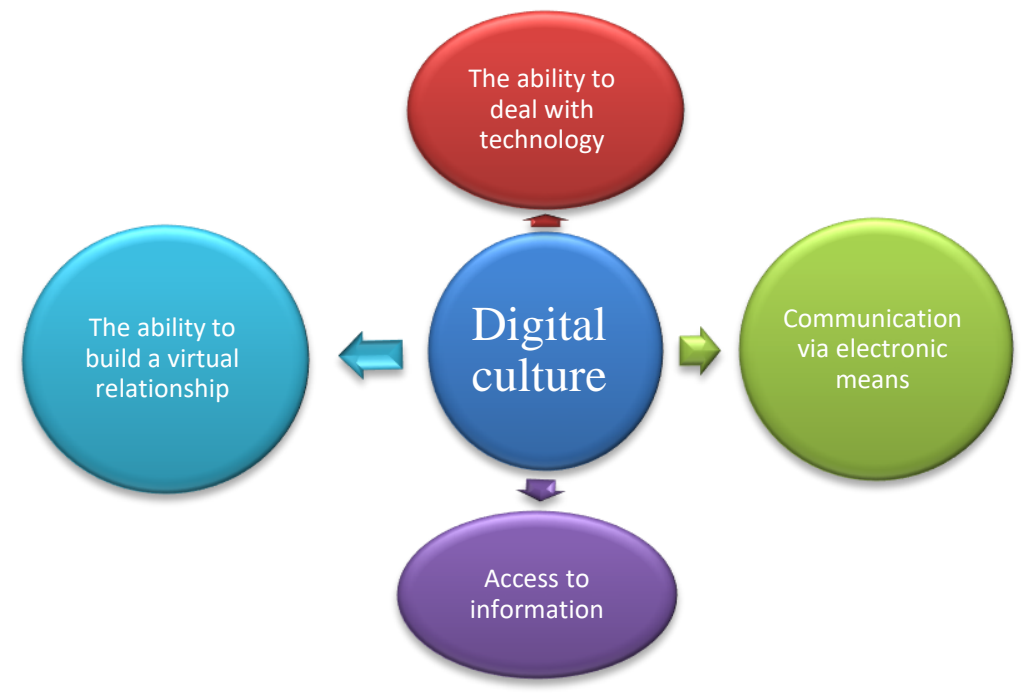

Figure 1.

From the above, digital culture refers to new cultural data as a result of the new electronic technology use, and the resulting gap between those who are able to obtain the latest information technology and easily obtain information by using the internet to communicate with computers, and those who are unable to obtain information due to the lack of internet services for them and the difficulty of their access to the internet networks in general, which is known as the digital barrier, the electronic gap, or the digital divide (Pavel, 2010).

In parallel with these developments, the digital world has increasingly penetrated the field of education and skills, as technologies are gradually being used to deliver education, knowledge, and skills in innovative ways, and this penetration is coupled with future changes in work style and pattern, and given the increasing use of rapidly changing digital technologies in the workplace, the need has emerged for new skills, the use of these technologies has contributed to transforming learning and skill development in to a life-long process, and therefore it is imperative that individuals now continue to develop and renew their skills and knowledge to keep up with the continuous innovations and new developments in the digital world (Cleman, 2017).

The study (Knox, 2014) shows the necessity of integrating digital technology in to the educational system to provide an advanced educational environment in which the digital technology basic structures are optimally used, as students build through them their educational experiences by learning how to use multiple sources of knowledge and knowing the assistive technology means to be able to access to information on the internet, and it leads to an increase in the knowledge production, and opportunities for communication between a large number of students and teachers in all parts of the world, and (Yanga, 2016) study suggested that integrating digital culture and its tributaries in to university education will cause fundamental changes in all elements and the educational system components affect the "educational cost" system, it is expected that the digital achievements integration and all the fourth industrial 
revolution results in the educational system will reduce the cost of education to the maximum extent possible and enhance the interaction between the teacher and the learner.

In This Regard, the 2030 development strategy included many ambitious and effective aims and programs for development and sustainability, including the orientation towards technology and its adaptation in educational work through the digital transformation program which is one of the 2020 national transformation programs, also the Saudi educational ministry supports the transformation of the educational environment to the digital environment and enabling students to interact and benefit from modern technologies, and equip them with the personal and technical skills necessary for the positive use of technology, to preserve their identity and enhance their legacy, by supporting and launching some promising technical initiatives and projects and various programming competitions to open up wide areas for creativity.

So it can be said that the digital culture has expanded students' experiences and contributed to adding an encyclopedia of concepts and knowledge to their world, thus transcending geographical and temporal boundaries towards the culture of other peoples, but it has placed the teacher in front of a major challenge towards developing his digital skills and continuous training on them, and on the various technical systems and programs and its means to be an active member of the educational system.

\section{Literature Review}

Based on the technological development importance, the digital e-culture established by it, and the opportunities it provided to enter the digital technology community, some researchers have been interested in studying the reality of digital culture to reach an appropriate vision for activating digital culture among students, Battous and Wesam study (2011) knows the contribution extent of broadcasting websites to spreading digital culture in Algerian society through the presence of digital content that contributes to changing trends and forming cultures in Algerian society and digital culture especially through the presence of radio digital content, also radio websites are keen to provide interactive services to consolidate their relationship with society either directly or through e-mail and opinion polls.

While Nabti and Bottemet Study (2012) aimed to find out the extent to which a sample of Algerian society represented by doctoral students was represented by the led system, which is an educational program that includes three stages (bachelor's stage, master's stage, and doctorate stage) in the libraries specialization at Constantine university only at the Arab world level for the goals of this society through dealing with this sample with the distinct cultural indicators of Algerian society, such as the phone, computer, and the internet, and the study sample consisted of (14) doctoral students in the library and information field, the study used the case study methodology and the design of a questionnaire as a tool to collect the study data, it included (32) questions distributed on two paths one for fixed and mobile phone equipment, and another for the computer and internet tool, the study results showed the difficulty of connecting to the network by relying on the phone, and that the internet in its current form is not dependent on it to spread and expand the digital culture concept despite its availability among most of the study population, so the study recommends the intervention of the concerned authorities to implement the 2013 electronic Algeria strategy.

While Hamshari study (2016) clarified the positive and negative effects of digital culture on university students from the students' viewpoint of the educational sciences faculty at Zarqa university and their attitudes towards it, the study sample consisted of (211) students in the educational sciences faculty, and the results showed that the social, personal, and economic positive effects of the digital culture that received high grades, while the academic effects received a medium grade, and all the negative personal, social, academic and economic influences received medium grades, and the results also showed that there were no statistically significant differences of the students grades, and any effect is due to variables of gender, academic year and specialization and that their attitudes towards this culture were positive and high, while Gouseti, (2017) study aimed to shed light on the digital practices of doctoral students, and the study followed the descriptive method, and the interview is used as a tool for collecting data and information, and interviews were held with (12) Ph.D. students at a higher education institution in the united kingdom, and the study concluded that Ph.D. students practice seven distinct types of engaging with digital technologies, and virtual societies, so the stereotype of doctoral studies differs due to the actual practice of digital culture.

A Stady by Pomwavey study (2018) aimed to explore how students invested their technological skills in accessing knowledge and information to maintain a strong link between technical skills and new developments resulting from the digital environment that affect their role as learners and researchers, and the study was based on the descriptive method and the study sample consisted of (136) masters students at the economics faculty to assess their technological capabilities and determine the place occupied by digital culture in their university career, and the study 
found that the students who lack in-depth knowledge of advanced technological tools and build new knowledge believe that technology is easy to use if the technological infrastructure is available.

Abu Amer's study (2019) entitled "the level of digital culture among a sample of fathers and mothers in the governorates of Ghaza strip" crystallized the level of digital culture among a sample of fathers and mothers in the governorates of the Gaza strip from their point of view, and the study used the descriptive method, and the questionnaire was designed as a study tool that contains (54) items were distributed in three domains: digital knowledge, digital skills, and digital trends, they were applied among a random sample of (425) fathers and mothers who had children in middle school, the study results concluded that the digital culture level among the study sample came below expectations, which indicates a deficiency in the digital culture level, weakness in knowledge related to the basics of using technology, and low awareness of the importance of monitoring their children's electronic activities and directing them to avoid the technology risks to them.

In this regard, Abdu al-Qadir's study (2019) comes to identify the reality and mechanisms of promoting digital culture in light of the requirements of a knowledge-based economy from the educational graduate students viewpoint in Egyptian universities, and the study used the descriptive survey method, and a questionnaire consisting of (54) items was applied among a sample consists of (286) male and female students from five Egyptian universities, and the study results showed that the sample members agreed to a large degree on the reality of the availability of digital literacy skills for postgraduate educational students in Egyptian universities, and the mechanisms for their enhancement, on the other hand, the field study results showed that there were no statistically significant differences due to the gender and the study stage variables while there were significant differences according to the program variable in favor of master's students.

By extrapolating the relevant previous studies, it is noted that most of them are field studies that dealt with digital culture and its impact on the university student, such as: Hamshari study (2016), Gouseti study (2017), and Pomwavey study (2018), while Abdul Qadir's study (2019) is one of the first studies that sought to employ digital culture in light of the requirements of a knowledge-based economy among graduate students, and the study of Abu Amer (2019) which focused on measuring the digital culture level among a sample of parents, and these studies are similar to the current study indirectly addressing the role of university education in promoting digital culture and the ways to activate it while this study differs with previous studies in that it used multiple variables such as: gender, specialization, and academic year to demonstrate the reality of practicing digital culture among students of the education faculties at the university, and the obstacles and problems facing its implementation and the university's efforts to activate it.

\section{Research Methodology}

To achieve the main research aim and its sub-objectives, the research relied on the analytical descriptive method, and the research relied on the field study that included the distribution of questionnaires on the sample members and the use of the statistical analysis program (SPSS) to analyze the data and this research relied on the analytical descriptive method to analyze the data, including frequencies, ratios, arithmetic mean and standard deviation, the study sample consisted of (180) male and female students in the education faculties at prince Sattam bin Abdulaziz university, and table (1) shows the distribution of the sample members as follows:

Table 1. The Distribution of the Sample Members According To Gender, Specialization and the Academic Year

\begin{tabular}{cccc}
\hline Variables & Categories & Frequency & Ratio \\
\hline Gender & Male & 80 & 44.5 \\
& Female & 100 & 55.6 \\
Specialization & Education & 107 & 59.4 \\
& Kindergarten & 73 & 40.6 \\
Academic year & First & 45 & 25.0 \\
& Second & 39 & 21.7 \\
& Third & 49 & 27.2 \\
& Fourth & 47 & 26.1 \\
& & & $\mathbf{1 8 0}$ \\
\hline
\end{tabular}


It is evident from the data of table (1) that the highest percentage of individuals in the study sample is (55.6\%), and then it is followed by males at $(44.4 \%)$, the table data also shows the students characteristics of the education faculties at the university in terms of specialization and the academic year, so the researchers found that the majority of individuals whose specialization education were (59.4\%), and in the second class came the kindergarten specialization, which was $(40.6 \%)$, and in terms of the academic year, the study found that $(27.2 \%)$ of the sample of undergraduate students were in the third year, then came the fourth year percentage of $(26.1 \%)$ then came $(25.0 \%)$ the first year, while the lowest percentage of representation for the academic year was the second year which is (21.7\%), a questionnaire was designed as the main tool for collecting information and data, and the questionnaire consisted of two main parts, including demographic data (gender, the academic year, and specialization) and other targeted questions that included three paths.

Table 2. "Alpha Stability" Coefficient, Correlation Coefficients (Internal Consistency) and Repetition Stability of the Study Tool

\begin{tabular}{cccc}
\hline Field & No. of Items & Repetition Stability & Internal Consistency \\
\hline The Reality of Promoting Digital Culture & 12 & 0.91 & 0.84 \\
Obstacles To Implementing Digital Culture & 10 & 0.86 & 0.72 \\
Efforts To Develop A Digital Culture & 10 & 0.92 & 0.89 \\
\hline
\end{tabular}

It is evident from the previous table that the search tool has high stability coefficients, which gives reliability in its use, and table (2) indicates statistically significant internal consistency coefficients at the level of significance (0.01) between the fields of the tool on one hand and between it and the total score of the tool on the other hand which confirms the validity of the tool to measure what it is designed for.

The range $(5-1=4)$ was calculated, then divided by the number of cells of the scale to get the correct cell length, i.e. $(4 / 5=0.80)$, after that, this value was added to the lowest value in the scale (or the beginning of the scale which is the correct one) to determine the upper limit of this cell and the length of the cells in the table (3).

Table 3. Cell Length to Explain Mean Averages

\begin{tabular}{ccc}
\hline No. & Extent & Verbal estimation \\
\hline 1 & $1.00-1.79$ & Very Small \\
2 & $1.80-2.59$ & Small \\
3 & $2.60-3.39$ & Medium \\
4 & $3.40-4.19$ & High \\
5 & $4.20-5.00$ & Very Large \\
\hline
\end{tabular}

\section{Results and Discussions}

To answer the first research question, "what is the reality of digital culture among students of education faculties at prince Sattam bin Abdulaziz University?" and the table below illustrates that. 
Table 4. The Arithmetic Means, Standard Deviations, and the Order of the Sample Individuals 'Grades of the Digital Culture Reality among Students of the Education Faculties at Prince Sattam Bin Abdulaziz University

\begin{tabular}{|c|c|c|c|c|c|}
\hline $\begin{array}{l}\text { No. of } \\
\text { Items }\end{array}$ & Items & Mean & $\begin{array}{r}\text { St. } \\
\text { Deviation }\end{array}$ & Rank & $\begin{array}{r}\text { Direct } \\
\text { Degree }\end{array}$ \\
\hline 1 & $\begin{array}{l}\text { The student can search databases of information over the } \\
\text { internet. }\end{array}$ & 4.14 & 0.84 & 1 & High \\
\hline 5 & He can use social media effectively. & 4.13 & 0.99 & 2 & High \\
\hline 2 & $\begin{array}{l}\text { Able to save, classify, and retrieve electronic information } \\
\text { sources. }\end{array}$ & 3.76 & .920 & 3 & High \\
\hline 8 & $\begin{array}{l}\text { He can employ (mobile/ blackboard/ e-mail) in solving } \\
\text { duties and assignments. }\end{array}$ & 3.75 & 1.03 & 4 & High \\
\hline 4 & $\begin{array}{l}\text { mobile applications are used to participate in discussion } \\
\text { forums with others in the field }\end{array}$ & 3.73 & .900 & 5 & High \\
\hline 3 & $\begin{array}{l}\text { The student can see the latest scientific findings in the } \\
\text { field of specialization. }\end{array}$ & 3.66 & 1.01 & 6 & Medium \\
\hline 7 & Can use (Google drive) to store and retrieve files. & 3.63 & 1.07 & 7 & Medium \\
\hline 9 & $\begin{array}{l}\text { He can get electronic information sources in (doc / pdf / } \\
\text { ppt) format. }\end{array}$ & 3.63 & 1.05 & 8 & Medium \\
\hline 6 & $\begin{array}{l}\text { Proficient in obtaining information sources from the } \\
\text { electronic digital library. }\end{array}$ & 3.61 & 1.08 & 9 & Medium \\
\hline 12 & $\begin{array}{l}\text { The student respects the intellectual property rights of the } \\
\text { electronic information available over the internet. }\end{array}$ & 3.38 & 1.22 & 10 & Medium \\
\hline 11 & $\begin{array}{l}\text { Make sure to read the content of software and application } \\
\text { agreements before agreeing to them. }\end{array}$ & 3.32 & 1.31 & 11 & Medium \\
\hline 10 & $\begin{array}{l}\text { (firewall) program is used to protect personal information } \\
\text { and files. }\end{array}$ & 3.03 & 1.26 & 12 & Medium \\
\hline \multicolumn{2}{|c|}{ The Reality of Promoting Digital Culture } & 3.65 & 0.67 & & Medium \\
\hline
\end{tabular}

Table 4 shows that the means and standard deviations of the reality of promoting digital culture are arranged in descending order, and the degree of their application in the education faculties at prince Sattam bin Abdulaziz university from the students' point of view, it ranged between $(3.03-4.14)$, where the item (1) which states: "the student can search databases on the internet" came in the first place, with an arithmetic average of (4.14) and a high degree of application, this may be attributed to the fact that the internet is an integral part of students 'lives, and students must benefit from the huge amount of information on the internet in the educational process and to apply what they learn inside the classroom and connect it to the outside world, and with the increasing use of electronic systems, students have to know how to search? Where are they looking? How do they acquire the critical thinking skills needed for the two electronic research processes? therefore training in research skills in online databases has become the basis for student success in studying, especially for students who are not fluent in the English language, and this result differs with the findings of the Pomwavey study (2018), which indicated that the use of technology in education constitutes a major challenge for students who are not accustomed to learning with it, because the fact that students live in the age of the internet does not mean that they are good at searching for sources in it, and that students have limited information about searching on the internet and limited skills in evaluation and criticism, while item (10) and firewall is used to protect personal information and files that ranked last with an arithmetic average of (3.03), and this result is due to students' lack of familiarity with the skills of using modern technologies, and their poor possession of skills to protect digital devices from penetration and theft of their data, and this result is consistent with the findings of Abu Amer's study (2019) which showed a deficiency in the level of digital culture among a sample of parents, and a lack of knowledge related to the basics of using technology.

To answer the second research question "what are the obstacles and problems that transform the implementation of digital culture among students of the education faculties?" estimated statistics were presented and arithmetic averages and standard deviations were extracted for the obstacles and problems that transform the implementation of 
digital culture among students of education faculties, the arrangement and the grade of each item of this domain, and the table below illustrates this.

Table 5. The Means, Standard Deviations, and the Order of the Sample Member's Grades of Obstacles and Problems Which Transforms the Implementation of Digital Culture among Students of the Education Faculties:

\begin{tabular}{|c|c|c|c|c|c|}
\hline $\begin{array}{l}\text { No. of } \\
\text { Items }\end{array}$ & Items & Mean & St. Deviation & Rank & $\begin{array}{c}\text { Direct } \\
\text { Degree }\end{array}$ \\
\hline 8 & $\begin{array}{l}\text { Lack of availability of classrooms equipped with } \\
\text { internet in the university. }\end{array}$ & 3.31 & 1.41 & 1 & Medium \\
\hline 7 & $\begin{array}{l}\text { The lack of training courses for students that develop } \\
\text { their digital culture. }\end{array}$ & 3.28 & 1.14 & 2 & Medium \\
\hline 9 & $\begin{array}{l}\text { The scarcity of students 'commitment to using } \\
\text { technology for academic purposes. }\end{array}$ & 3.28 & 1.24 & 2 & Medium \\
\hline 6 & $\begin{array}{l}\text { The digital culture has created new ways to cheat } \\
\text { exams. }\end{array}$ & 3.23 & 1.17 & 4 & Medium \\
\hline 4 & $\begin{array}{l}\text { The digital culture has led students to expose them to } \\
\text { false ideas. }\end{array}$ & 3.18 & 1.15 & 5 & Medium \\
\hline 1 & $\begin{array}{l}\text { Decreased students' knowledge of digital literacy } \\
\text { skills. }\end{array}$ & 3.14 & 1.14 & 6 & Medium \\
\hline 2 & Relying in the calendar on written tests only. & 3.13 & 1.19 & 7 & Medium \\
\hline 10 & $\begin{array}{l}\text { Difficulty using some computer programs such as; } \\
\text { zoom and blackboard. }\end{array}$ & 3.10 & 1.24 & 8 & Medium \\
\hline 3 & $\begin{array}{l}\text { The absence of university support for students to deal } \\
\text { with technological information. }\end{array}$ & 3.01 & 1.19 & 9 & Medium \\
\hline 5 & $\begin{array}{l}\text { The digital culture increased negative contact between } \\
\text { students at the university. }\end{array}$ & 2.93 & 1.16 & 10 & Medium \\
\hline & Obstacles To Implementing Digital Culture & 3.16 & 0.66 & \multicolumn{2}{|c|}{ Medium } \\
\hline
\end{tabular}

By reading table 5, it becomes evident that the obstacles to the realization of digital culture exist in an average degree, as the mean of the dimension reached (3.16), and the standard deviation (0.66), item (8) which states: "the lack of availability of classrooms equipped with the internet at the university" in first place, with an average of (3.31), due to the weakness of the infrastructure in terms of the availability of smart rooms and computer labs with the provision of internet connection service in addition to providing technical support, this result differs with what was included in the communications and information technology ministry report (2020) regarding the education ministry of developing a comprehensive plan to integrate technology in to education by launching a (national) computer project, which is one of the largest projects in information technology in the educational field in the kingdom, it aims to raise the level of faculty members in employing information technology in all educational activities, and the creation of an information environment appropriate to the needs of students and faculty members, the results also showed that item (5), which states that "digital culture has increased negative friction between students at the university," came in the last place with an average of (2.93), and the degree of approval was moderate, to the digital culture, it contributed to deepening the existing social relations between students by using mobile phones and e-mail, text messaging, enhancing their general knowledge, removing psychological and social barriers between them, strengthening and documenting existing friendships, and increasing the number of friends who share the same interests, and this result differs in part with what was confirmed by Zebon and Attia study (2016), the existence of negative effects of digital culture, such as internet addiction, academic and academic delay and the promotion of regional or ethnic intolerance.

To answer the third research question, "what are the efforts of prince Sattam bin Abdulaziz university in developing digital culture among students of education faculties?" estimated statistics were presented, and averages and standard deviations were extracted for prince Sattam bin Abdulaziz university's efforts in developing digital culture among students of education faculties and the following table shows that. 
Table 6. the averages, standard deviations, and the order of the sample member's grades for university efforts prince Sattam bin Abdulaziz in developing digital culture among students of the education faculties

\begin{tabular}{|c|c|c|c|c|c|}
\hline $\begin{array}{l}\text { No. of } \\
\text { Items }\end{array}$ & Items & Mean & St. Deviation & Rank & Direct Degree \\
\hline 4 & $\begin{array}{l}\text { The university provides the necessary facilities to use electronic } \\
\text { exams over the internet. }\end{array}$ & 3.93 & 1.01 & 1 & High \\
\hline 3 & $\begin{array}{l}\text { The university provides a university email to every student at the } \\
\text { university to find official channels between the faculty member } \\
\text { and the students. }\end{array}$ & 3.83 & 0.98 & 2 & High \\
\hline 1 & $\begin{array}{l}\text { The university offers training programs that provide students } \\
\text { with self-development skills in using digital technology. }\end{array}$ & 3.82 & 1.01 & 3 & High \\
\hline 2 & $\begin{array}{l}\text { The university provides opportunities for interaction via video } \\
\text { conferencing between faculty members and students. }\end{array}$ & 3.77 & 1.15 & 4 & High \\
\hline 9 & $\begin{array}{l}\text { the university provides many distinctive services that are made } \\
\text { available via university e-mail. }\end{array}$ & 3.77 & 1.13 & 4 & High \\
\hline 5 & $\begin{array}{l}\text { The university spreads the culture of digital learning among } \\
\text { students to gain sufficient awareness of the role of technology in } \\
\text { educational development. }\end{array}$ & 3.76 & 0.90 & 6 & High \\
\hline 8 & $\begin{array}{l}\text { The university's philosophy supports the application of the } \\
\text { self-learning concept through digital university teaching. }\end{array}$ & 3.74 & 0.95 & 6 & High \\
\hline 7 & $\begin{array}{l}\text { The university adheres to the international standards of the } \\
\text { faculty programs and designs them according to market needs by } \\
\text { expanding the use of technology. }\end{array}$ & 3.57 & 0.99 & 8 & Medium \\
\hline 10 & $\begin{array}{l}\text { The university provides quality teaching through cloud } \\
\text { computing that contributes to education faster and more } \\
\text { efficiently. }\end{array}$ & 3.56 & 1.21 & 9 & Medium \\
\hline \multirow[t]{2}{*}{6} & $\begin{array}{l}\text { The university encourages students to use the university e-book } \\
\text { instead of the paper-based book. }\end{array}$ & 3.46 & 1.16 & 10 & Medium \\
\hline & University efforts in developing digital culture & 3.72 & 0.71 & & High \\
\hline
\end{tabular}

Table 6 shows the existence of high approval by students of education faculties on all the university's proposed efforts in the questionnaire which would develop the digital culture among students of the education faculties at prince Sattam bin Abdulaziz university where all their responses were of a high degree except for three items on which their responses were of a moderate degree, the averages ranged between (3.46- 3.93), and the total average for this field was (3.72) which represent a high degree, the arithmetic averages of the students' responses to the education faculties indicated that the most important efforts of the proposed university to develop digital culture from the students' point of view were "the university provides the necessary capabilities to use electronic tests over the internet," with an average of (3.93), the second mechanism is of importance according to the opinions of students that "the university provides a university email for every student at the university to find official channels between a faculty member and students with an average calculation of (3.83) and in the third place of importance was "the university provides training programs that provide students with self-development skills in the use of digital technology" its average was (3.82), the average of the fourth and fifth items: "the university provides opportunities for interaction via video conferencing between a faculty member and students" and "the university provides many distinct services that it provides via university e-mail " in which the university's main efforts in developing digital culture among its students with a mean (3.77), then "the university spreads the culture of digital learning among students with the aim of adequate awareness of the technology role in educational development" was in the sixth place among the most important mechanisms with a relative weight of (3.67), and in the seventh place in terms of important mechanisms from the students' point of view, through digital university teaching, with an average of (3.64), and these results may be attributed to the fact that all students see that these mechanisms are among the main factors for the university's development of digital culture, computer devices, internet service, computer laboratories, and the application of computer systems would provide the best electronic services and speed the completion of job tasks, the information technology and distance education deanship has attracted much modern software and contracted with local and international companies specialized in the information technology fields to employ technology in the 
education service, the item "the university encourages students to use the electronic university book instead of the book in paper form" was the last among the items on the university's efforts to develop digital culture from the students' viewpoint of the education faculties this is due to the defects of the electronic books as they need an electronic device and software that allows reading, and the hyperlinks associated with pages on the internet that need a connection and this result differs with the findings of (Gouseti, 2017) study which showed that the e-book is attractive and fun for the student, as it provides him with an opportunity to interact with the learning content, it is also considered the ideal solution to some of the traditional education problems.

To answer the fourth research question, "are there statistically significant differences between the study sample responses at the level of (0.05) according to the study variables (gender, specialization, and academic year)?" estimated statistics were presented, and averages, standard deviations and the three-way analysis of variance were extracted to show the differences in the digital culture reality among students of education faculties at prince Sattam bin Abdulaziz university according to the variables (gender, specialization, and academic year), and the table below shows that.

Table 7. Means and standard deviations of the digital culture reality among students of the education faculties at prince Sattam bin Abdulaziz University according to the gender, specialization, and academic level variables

\begin{tabular}{ccccc}
\hline Variables & Categories & Number & Mean & St. Deviation \\
\hline Gender & Male & 80 & 3.37 & 0.67 \\
& Female & 100 & 3.87 & 0.59 \\
Specialization & Education & 107 & 3.58 & 0.74 \\
& Kindergarten & 73 & 3.75 & 0.55 \\
Academic Year & First & 45 & 3.48 & 0.66 \\
& Second & 39 & 3.40 & 0.62 \\
& Third & 49 & 3.61 & 0.47 \\
& Fourth & 47 & 4.06 & 0.74 \\
\hline
\end{tabular}

Table 7 shows an apparent variation in the averages and standard deviations of the digital culture reality among students of education faculties at prince Sattam bin Abdulaziz University due to the different categories of the gender, specialization, and academic level variables and to show the significance of the statistical differences between the averages triple variance analysis was used, table (8).

Table 8. Analyzes the triple variance of gender, specialization, and academic level effect on digital culture reality of the education faculties students at prince Sattam bin Abdulaziz University

\begin{tabular}{cccccc}
\hline Source of Variance & Sum of Squares & Free Degrees & Mean Squares & F Value & Statistical Significance \\
\hline Gender & 7.008 & 1 & 7.008 & 19.168 & .000 \\
Specialization & 1.927 & 1 & 1.927 & 5.271 & .023 \\
Academic Year & 4.101 & 3 & 1.367 & 3.739 & .012 \\
Wrong & 63.612 & 174 & 0.366 & & \\
Total & 82.373 & 179 & & & \\
\hline
\end{tabular}

\section{From this table 8, it is noted that:}

There were statistically significant differences $(\alpha=0.05)$ in the degree of the digital culture reality among students of education faculties at prince Sattam bin Abdulaziz university due to the effect of gender, as the value of (q) calculated was (19.168) with a statistical significance of (0.000), and the differences came in favor of females which indicates the presence of digital culture among females more than males, and this may be due to the fact that females realize the importance of digital culture as a requirement of the labor market, so they are keen to train themselves in technology or obtain specialized training courses, and they are also more in contact with modern technology and access to a network due to the technological variables occurring in society, and this differs according to (Hamshari, 2016) study which showed that there were no statistically significant differences that can be attributed to the gender variable and that students 'attitudes about digital culture were positive and high.

There were statistically significant differences $(\alpha=0.05)$ in the degree of the digital culture reality among students of education faculties at prince Sattam bin Abdulaziz university according to specialization (education, kindergarten) variable as the calculated value (q) reached (5.271) and its statistical significance (0.023), and the differences came 
in favor of kindergarten specialization, and this result can be attributed to the belief of kindergarten students that children are the future generation, therefore digital culture must be employed from an early age in a manner that does not conflict with the culture of society.

There were statistically significant differences $(\alpha=0.05)$ in the degree of the digital culture reality among students of education faculties at prince Sattam bin Abdulaziz university due to the impact of the academic year as the calculated value of (q) was (3.739) with a statistical significance of (0.012) and to clarify the differences the statistically significant evenness between the means, the dimensional comparisons were used in a curated way, as shown in table 9.

Table 9. dimensional comparisons by chef it way of the academic year impact on the digital culture reality of education faculties students at prince Sattam bin Abdulaziz university

\begin{tabular}{cccccc}
\hline Academic Year & Mean & First-Year & Second-Year & Third-Year & Fourth-Year \\
\hline First & 3.48 & & & \\
Second & 3.40 & .07 & & \\
Third & 3.61 & .13 & .21 & \\
Fourth & 4.06 & $* .58$ & $* .66$ & $* .45$ & \\
\hline
\end{tabular}

* Significance at the level $(=\mathbf{0 . 0 5})$.

Table 9 shows that there were statistically significant differences in the degree of the digital culture reality among students of education faculties at prince Sattam bin Abdulaziz university between the fourth year and the first year on one hand, and the second and third year on the other hand and the differences came in favor of the fourth year and this is because the students of the education faculties in the fourth year are the group that has experienced technology most since its inception through the curricula and became more familiar with the basic knowledge and skills of digital technology, as well as their positive view of the importance of technology in their lives, This result is consistent with what was presented by the study (Hamshari, 2016).

\section{Conclusions}

- The mean of the whole tool of the reality of digital culture items among students of the Education Faculties at Prince Sattam Bin Abdulaziz University came with a medium degree.

- The mean of the whole tool of the obstacles and problems items that transform the implementation of digital culture among the students of the Education Faculties came with a moderate degree.

- The mean of the whole tool of the university Prince Sattam bin Abdulaziz University's efforts in developing digital culture items among students of Education Faculties came with a high degree.

- There are statistically significant differences in the reality of digital culture degree among students of the education faculties at the university according to the variables of: gender (in favor of females), specialization (in favor of kindergarten), and according to the variable of the academic year (in favor of the fourth year).

\section{Recommendations}

Based on the review of the study cognitive aspect and the relevant literature, and discussion of the study results, the study recommends the following:

- Setting a strategic plan to enhance the digital culture and digital transformation at the university to invest modern communication technologies in supporting and developing educational technologies at the university.

- The university provides the necessary financial and administrative support to enter the digital age and qualify faculty and students to deal with the electronic environment and the transition towards digital culture.

- Planning training programs or students to enhance their digital skills and take advantage of the internet and social media sites to develop their skills positively using digital media.

- Including the digital culture concepts, processes of digital transformation, and methods of activating them within educational institutions in the curricula.

- Providing digital libraries and electronic learning resources and making them available to all students.

\section{References}

Abdel Qader, Mudan (2019). "Digital culture among postgraduate educational students in Egyptian universities in light of the requirements of a knowledge-based economy, "Journal of Education at Al-Azhar University, 184(3), 
1593-1537.

Abu Amer, Amal (2019). "the level of digital culture among a sample of parents in the governorates of Ghaza strip," Journal of the Islamic University for Educational and Psychological Studies, Islamic University of Gaza, 27(6), 193-215.

Al Zobon, Muhammad, Attia, Nariman (2016). "the role of the Jordanian educational system in limiting the negative impact of modern means of communication technology in educating young people from the viewpoint of their teachers ”, Jordanian Journal of Educational Sciences at Yarmouk University, 2(12), 169-180.

Anthony, k. (2015). Training therapists to work effectively online and offline within digital culture, British Journal of Guidance \& Counseling, 43(1), 36-42. https://doi.org/10.1080/03069885.2014.924617

Battous, Kamal, Wesam, Bin Zakka (2011). Radio websites and their role in spreading digital culture: a study on the regional radio in Jijel Algeria- the works of the twenty-second conference on information systems and services specialized in Arab information institutions: reality, challenges, and ambition, Khartoum, Arab federation for libraries and information, December 18-21, 1479-1455.

Cleman, Sarah gran (2017). Digital learning: education and skills in the digital age, California, Korsham institute for intellectual leadership, 1-23.

Economic and Social Commission for Western Asia (ESCWA) (2018). Technology for sustainable development, creation of decent work opportunities and youth empowerment in Arab countries, Beirut, United Nations center for women's affairs.

Gouseti, a. (2017). Exploring doctoral students' use of digital technologies: what do they use them for and why? Educational Review, 69(5), 638-654. https://doi.org/10.1080/00131911.2017.1291492

Hamshari, Omar (2016). "the effects of digital culture on university students from the viewpoint of students of the faculty of educational sciences at Zarqa university and their attitudes towards it", Zarqa Journal for Research and Humanities, Jordan, college of educational sciences in Zarqa, 16(1), 45-61.

Knox, j. (2014). Digital culture clash: "massive" education in the e-learning and digital cultures mood, Distance Education, 35(2), 164-177. https://doi.org/10.1080/01587919.2014.917704

Mahmoud, Amal Salah (2016). "The effect of digital transformation of knowledge on the information culture on the specialties of arts and humanities from the faculty members of Arts in Qena", Cybrarians journal, Cairo, issue (43), available http://www.journal.cybrarians.org/index.php?option=com_content\&view=article\&id=744:amahmoud\&catid=29 4:papers \&Itemid $=107$.

Nabti, Muhammad al-Saleh, Bottemjt, Sanaa (2012). Digital culture is a feature of the knowledge society: a field study with doctoral students in the department of library science at the university of Constantine- the twenty-third conference on government and society and integration in building Arab knowledge societies, Doha, Arab federation of libraries and information, November 18-20, part (3), 2071-2087.

Pavel, Abdullah (2010). The role of higher education institutions in breaking the digital barrier- book (28) in a series of publications toward a knowledge society, Jeddah, center for strategic studies, king Abdulaziz University, 1-115.

Pomwavey, Bahja (2018). "attitudes of Algerian students towards digital culture and its impact on the use of technology in light of the technology acceptance model”, Journal of Humanities and Social Sciences, Algeria, Abdel Hamid Mehri university- Constantine 2, issue (50), 226-237.

Tashour, Muhammad (2014). "digital spaces and their role in reducing the digital divide", Jordanian journal of libraries and information, Jordan, Jordan association of libraries and information, 49(2), 47-64.

The ministry of communications and information technology (2020). A digital homeland, an ambitious nation, Riyadh, the ministry's media center.

Yanga, J. Y., \& Yen, Y. C. (2016). college students' perspectives of e-learning system use in high education, Asian Journal of Education and Training, 2(2), 53-62. https://doi.org/10.20448/journal.522/2016.2.2/522.2.53.62

\section{Copyrights}

Copyright for this article is retained by the author(s), with first publication rights granted to the journal.

This is an open-access article distributed under the terms and conditions of the Creative Commons Attribution license (http://creativecommons.org/licenses/by/4.0/). 